\title{
AVALIAÇÃO POR PARES EM DIVULGAÇÃO CIENTÍFICA
}

\author{
Isabel Amélia Costa Mendes ${ }^{1}$ \\ Maria Helena Palucci Marziale ${ }^{2}$
}

O envolvimento de avaliadores externos no processo de editoração de periódicos científicos vem ocorrendo há mais de dois séculos, disseminando-se pouco a pouco esta prática a ponto de registrar-se nos últimos cinqüenta anos a adoção desta sistemática pela maioria dos respeitáveis periódicos.

A escolha deste grupo de avaliadores é feita pelos editores, com base em determinados critérios, especialmente o de reconhecimento da competência do avaliador como pesquisador produtivo e atualizado no assunto a que se refere o artigo a ser analisado. Além deste indicador fundamental para a escolha do avaliador pelos editores, para cada artigo a ser apreciado, outros aspectos contam na outorga desta responsabilidade: a capacidade de avaliar se 0 artigo atrairá leitores de outras especialidades ou mesmo de outras áreas; a demonstração de que 0 avaliador conhece a missão, interesses e normas da Revista; e, por fim, mas tão importante quanto os três requisitos anteriores, que os avaliadores seja isento nos julgamentos.

Em suma, para que os periódicos cumpram sua missão é imprescindível uma busca constante da excelência e, para tanto, é preciso que se contem com analistas que tenham segurança na elaboração de pareceres com imparcialidade tanto no apontamento dos aspectos positivos como negativos - o que pressupõe experiência acadêmica.

Numa área em que a pesquisa é ainda emergente, é compreensível que se contem com um percentual restrito de pesquisadores experientes, o que redundaria em sobrecarga em termos de avaliação de artigos publicáveis, se somente esses fossem acionados no processo. No caso da Enfermagem brasileira, onde há descompasso entre a disponibilidade de pesquisadores experientes e o crescimento dos periódicos especializados, os avaliadores melhor capacitados são insuficientes para absorver a demanda e dar conta da responsabilidade no ritmo que os periódicos desejam (e que precisam cumprir, para manter ou elevar o nível de avaliação conquistado!).

Exatamente por considerarmos vital a contribuição dos consultores aos periódicos de modo geral, e a este em particular ${ }^{(1)}$, como editores também devemos contribuir com o apontamento de dificuldades a serem superadas pela própria comunidade científica de modo a desempenhar seu papel com qualidade permanentemente reconhecida. Porisso, convidamos nossos leitores para uma reflexão sobre a importância e necessidade de se incluir conteúdos sobre divulgação científica nos programas de formação de doutores. Geralmente, nestes programas, o foco é a formação do futuro doutor para a compreensão e condução de pesquisas.

Urge que se atente também para a exploração do processo de avaliação do produto da investigação científica, de modo que se possa contar com pesquisadores cada vez mais experientes e que enriqueçam o processo e o resultado da edição científica.

Ademais, como na sociedade do conhecimento a educação é concebida como a criadora do capital humano, é fácil entender que investimentos tanto em geração como na disseminação do saber constituem alicerces do progresso do profissional, da profissão e da mudança social $^{(2)}$.

Adotando como estratégia a exploração do conhecimento explícito e do conhecimento tácito como unidades estruturais básicas que se complementam ${ }^{(3)}$, podemos obter uma dinâmica no desenvolvimento de competências em avaliação que favoreçam 0 atingimento dos resultados que buscamos.

\footnotetext{
${ }^{1}$ Professor Titular, e-mail: iamendes@eerp.usp.br; ${ }^{2}$ Professor Livre-Docente, e-mail: marziale@eerp.usp.br. Editores da Revista Latino-Americana de Enfermagem da Escola de Enfermagem de Ribeirão Preto da Universidade de São Paulo, Centro Colaborador da OMS para o desenvolvimento da pesquisa em enfermagem
} 


\section{REFERÊNCIAS BIBLIOGRÁFICAS}

1. Marziale MHP. O processo de revisão de manuscritos e a melhoria da qualidade das publicações. Rev Latino-am Enfermagem 2001 setembro-outubro; 9(5):1.
2. Mendes IAC. Criação, divulgação e ação: o saber em movimento.

Rev Latino-am Enfermagem 1995 janeiro; 3(1):1-2.

3. Nonaka I, Takeuchi H. Criação de conhecimento na empresa. Trad. Ana Beatriz Rodrigues, Priscila Martins Celeste. Rio de Janeiro (RJ): Campus; 1997. 


\section{PEER REVIEW IN SCIENTIFIC DISSEMINATION}

The involvement of external reviewers in the editorial process of scientific journals has occurred for over two centuries. Such practice has been gradually disseminated to the extent that, in the last fifty years, this procedure has been adopted by most respectable journals.

The selection of a group of reviewers is made by editors based on certain criteria, particularly on the recognition of the reviewer's competence as a productive researcher who is updated in the subject to which the analyzed article refers. In addition to this fundamental indicator for the choice of a reviewer for each article, other aspects are taken into account in the assignment of such responsibility: the capacity to evaluate if the article will attract readers from other specialties or fields; the demonstration that the reviewer recognizes his mission, the Journal's interests and guidelines, and finally, but as important as the three previous requirements, that the reviewers be impartial in their judgements.

In summary, in order for journals to accomplish their missions, a constant search for excellence is essential, and to that end, it is necessary to rely on analysts that feel secure to elaborate impartial reviews as well as to point out both positive and negative aspects, which requires academic experience.

In a field where research is still emerging, it is understandable that a restricted number of experienced researchers can be counted on, which results on an overload in terms of the evaluation of publishable articles if only such researchers are to be assigned to participate in the review process. In the case of Brazilian Nursing, where there is a discordance between the availability of experienced researchers and the growth of specialized journals, the number of better prepared reviewers is insufficient to absorb the demand and responsibility to comply with the deadlines required by journals (which must be met in order to maintain or increase the level of evaluation that has been achieved!).

It is precisely because, we consider the contribution given by consultants to journals in general and to ours ${ }^{(1)}$ in particular to be vital, as editors, we must also contribute to point out the difficulties to be overcome by the scientific community itself so that it can play its role with permanently recognized good quality standards. Therefore, we invite our readers to a reflection on the importance and need to include contents concerning scientific dissemination in doctoral programs. In general, such programs focus on the education of future doctors for the understanding and conduction of research.

It is urged that attention also be given to the exploration concerning the process of evaluation of scientific investigation production so that more and more experienced researchers, who will enrich the process and results of scientific edition, can be relied on.

Furthermore, since education is conceived in the society of knowledge as the creator of human capital, it is easy to understand that investment on both the generation and the dissemination of knowledge constitutes the foundations for the profession, professionals and social change ${ }^{(2)}$.

By adopting the exploration of explicit and tacit knowledge as basic structural units that complement each other ${ }^{(3)}$, we can reach a dynamics in the development of competence in evaluations that will favor the achievement of the results we are seeking.

\footnotetext{
${ }^{1}$ Full Professor, e-mail: iamendes@eerp.usp.br; ${ }^{2}$ Associate Professor, e-mail: marziale@eerp.usp.br. Editors of Revista Latino-Americana de Enfermagem de Ribeirão Preto of the University of São Paulo at Ribeirão Preto College of Nursing - WHO Collaborating Centre for Nursing Research Development
} 


\section{REFERENCES}

1. Marziale MHP. O processo de revisão de manuscritos e a melhoria da qualidade das publicações. Rev Latino-am Enfermagem 2001 setembro-outubro; 9(5):1.
2. Mendes IAC. Criação, divulgação e ação: o saber em movimento.

Rev Latino-am Enfermagem 1995 janeiro; 3(1):1-2.

3. Nonaka I, Takeuchi H. Criação de conhecimento na empresa. Trad. Ana Beatriz Rodrigues, Priscila Martins Celeste. Rio de Janeiro (RJ): Campus; 1997. 


\section{EVALUACIÓN POR PARES EN LA DIVULGACIÓN CIENTÍFICA}

El compromiso de evaluadores externos en el proceso editorial de las revistas científicas viene ocurriendo hace más de dos siglos, diseminándose poco a poco ésta práctica hasta el punto de registrarse en los últimos cincuenta años la adopción de éste sistema por la mayoría de los periódicos respetables.

La selección de este grupo de evaluadores es hecha por los editores, con base en determinados criterios, especialmente el de reconocimiento de la competencia del evaluador como investigador productivo y actualizado en el asunto al que se refiere el artículo a ser analizado. Además de éste indicador fundamental para la selección del evaluador por parte de los editores, para cada articulo a ser apreciado, otros aspectos cuentan en la asunción de ésta responsabilidad: La capacidad de evaluar si el artículo atraerá lectores de otras especialidades o aun de otras áreas; la demostración de que el evaluador conoce la misión, intereses y normas de la revista; finalmente y tan importante como los tres requisitos anteriores, que los evaluadores estén exentos de juicios.

En suma, para que las revistas cumplan su misión es imprescindible una búsqueda constante de la excelencia y para esto, es preciso que se cuente con analistas que tengan seguridad en la elaboración de pareceres con imparcialidad tanto en la señalización de los aspectos positivos, como de los negativos - lo que supone experiencia académica.

En un área en que la investigación es todavía emergente, es comprensible que se cuente con un porcentaje restringido de investigadores experimentados, lo que redundaría en sobrecarga en términos de evaluación de artículos para publicar, si solamente éstos fuesen diligenciados en el proceso. En el caso de la Enfermería Brasileña, en donde ha desequilibrio entre la disponibilidad de investigadores experimentados y e crecimiento de las revistas especializadas, los evaluadores mejor capacitados son insuficientes para absorber la demanda y dar cuenta de la responsabilidad en el ritmo que las revistas desean (y que necesitan cumplir, para mantener o elevar el nivel de evaluación conquistado).

Exactamente porque consideramos vital la contribución de los consultores a las revistas de modo general y a ésta de modo particular ${ }^{(1)}$, como editores también debemos contribuir con el señalamiento de dificultades a ser superadas por la propia comunidad científica de modo a desempeñar su papel con calidad permanentemente reconocida. Por eso, invitamos a nuestros lectores a reflexionar acerca de la importancia y necesidad de incluir contenidos sobre divulgación científica en los programas de formación de Doctores. Generalmente, en éstos programas, el foco es la formación del futuro Doctor para la comprensión y conducción de investigaciones.

Es urgente que se coloque particular atención también para la exploración del proceso de evaluación del producto de la investigación científica, de modo que se pueda contar con investigadores cada vez más experimentados y que enriquezcan el proceso y el resultado de la edición científica.

Además, como en la sociedad del conocimiento la educación es concebida como la creadora del capital humano, es fácil entender que inversiones tanto en generación como en la diseminación del saber, se constituyen en la base del progreso profesional, de la profesión y del cambio social ${ }^{(2)}$.

Adoptando como estrategia la exploración del conocimiento explícito y del conocimiento tácito como unidades estructurales básicas que se complementan ${ }^{(3)}$, podemos obtener una dinámica en el desarrollo de competencias en evaluación que favorezcan el alcance de los resultados que buscamos.

\footnotetext{
${ }^{1}$ Profesor Titular, correo electrónico: iamendes@eerp.usp.br; ${ }^{2}$ Profesor Libre-Docente, correo electrónico: marziale@eerp.usp.br. Editores de la Revista Latinoamericana de Enfermería de la Escuela de Enfermería de Ribeirão Preto de la Universidad de São Paulo, Centro Colaborador de la OMS para el desarrollo de la investigación en enfermería
} 


\section{REFERENCIAS BIBLIOGRÁFICAS}

1. Marziale MHP. O processo de revisão de manuscritos e a melhoria da qualidade das publicações. Rev Latino-am Enfermagem 2001 setembro-outubro; 9(5):1.
2. Mendes IAC. Criação, divulgação e ação: o saber em movimento.

Rev Latino-am Enfermagem 1995 janeiro; 3(1):1-2.

3. Nonaka I, Takeuchi H. Criação de conhecimento na empresa. Trad. Ana Beatriz Rodrigues, Priscila Martins Celeste. Rio de Janeiro (RJ): Campus; 1997. 